\title{
HAINAN CHAM, ANONG, AND EASTERN CHAM: THREE LANGUAGES, THREE SOCIAL CONTEXTS, THREE PATTERNS OF CHANGE ${ }^{1}$
}

\author{
Graham Thurgood \\ California State University, Chico
}

\begin{abstract}
Three separate languages are examined, each with a different sociolinguistic setting, and with each setting leading to a different pattern of grammatical change. The paper sketches the grammar changes and documents the associated social settings: specifically, how the language in question is used and whether outsiders are speaking the language. The paper supports the general conclusion (e.g., by Thomason \& Kaufman) that the most important factors in contactinduced change are social ones but more interestingly and more specifically, in regard to these three languages, it deals which sociolinguistic contexts for language correlate with the three quite distinct sets of outcomes.
\end{abstract}

\section{Introduction}

Language-internal pressures are not the only influence on the nature and direction of language change. In fact, in many cases, language contact is not just one influence but is the major influence providing an impetus that coincides with internal influences sometimes overpowering contradicting internal tendencies. When possible particular attention is paid to the sociolinguistic conditions under which three Southeast Asian languages have restructured under intense multilingual contact:

${ }^{1}$ Acknowledgements. I shall be astonished should all my errors prove minor and appreciative of corrections from the specialists. I wish to thank various reviewers for extremely useful feedback. It is has led to revisions in my thinking; I suspect where I have not taken the advice given me, I shall regret it. The research in this paper is supported in part by National Science Foundation Grant No. 60232 Endangered Languages in China. The Eastern Cham examples all come from the work of David and Doris Blood gathered roughly a quarter of a century ago, with the vast majority of them coming out of Doris Blood's texts. The section on Eastern Cham was totally reworked under the invaluable and detailed feedback given by Marc Brunelle; the improvements under his guidance make it a much better paper. The Anong data is from Sun Hongkai \& Liu Guangkun's work, both participants in the grant. The data is part of a remarkable collection study of Anong, a study spread over some 40 years, full of treasures (cf. Sun \& Liu 2005, which has just been translated (Sun \& Liu 2009)). I wish to thank Fengxiang Li and Ela Thurgood for their invaluable insights and suggestions, and John Davey for feedback on an earlier version. The Hainan Cham data is from the work of Zheng Yiqing with the help of Ouyang Jueya with other material from Ni Dabai, Ian Maddiesen, and Keng-Fang Pang. There are also fieldwork recordings done in Hainan in the summer of 2004 by Ela Thurgood, Ouyang Jueya, JiangDi, and Graham Thurgood. 
Hainan Cham, a Chamic language of Hainan; Anong, a Tibeto-Burman language of Yunnan; and Eastern Cham (Phan Rang Cham), a Chamic language of southern Vietnam.

These three languages have been picked because, despite the existence of a great deal of information about their linguistics, it is clear that the key to understanding their current structures lies in their social settings. In the descriptions below, the languages are briefly identified, the restructuring involved is characterized, and then the social setting is described in as much detail as is known and useful.

All three languages involve language maintenance but with quite different paths of change and quite distinct results: Hainan Cham has restructured under the influence of contact (what Ross (2003) has been terming 'metatypy', with Ross's emphasis on extending our understanding of the social contexts involved. Ross's metatypy is subsumed under what Thomason \& Kaufman (1988:50) term 'borrowing' and what Weinreich (1963 [1953]) terms 'grammatical interference'. Anong started out as a case of metatypy, restructuring moderately under the influence of Lisu; however, with far more intense restructuring as many of the ethnic Anong switch to Lisu, Anong is now in the last stages of language death and undergoing various types of attrition. Eastern Cham, although quite recently under influence from Vietnamese was, at the earliest stage, the ProtoChamic stage, subjected to intense bilingualism at the time of initial contact, including significant numbers of non-tutored adult learners shifting or becoming bilingual.

All three are examples of maintenance with restructuring and borrowing under contact, but the patterns of restructuring differ with the social settings. Anong ceased to be the primary language in any language setting. Hainan Cham has been reduced to the language of the village; outside of the village other languages are employed; Eastern Cham remained the major language of its speech community. In each case, the number of speakers differs significantly: Hainan Cham has between three and five thousand speakers, Anong has less than 62 fully-fluent speakers, and Eastern Cham has from 100,000 speakers. ${ }^{2}$ Although other factors play a role, the factors for which the evidence is clear will be discussed. ${ }^{3}$

\section{Case 1: Hainan Cham, a Chamic language of Hainan}

Hainan Cham, tsa: $n P^{32}$ (sometimes Anglicized as Tsat), is an Austronesian language once at various coastal locations along Hainan Island, now found near Sanya City. The 1982 census lists 4131 Hainan Cham people largely in the villages of Huihui and Huixin near Sanya, 3849 of whom still spoke Hainan Cham. In addition, virtually all adult Hainan Cham speakers also speak one or more Chinese dialects, typically Taiwanese (Fukienese) or Cantonese, the languages of business, and Mandarin, the language of school (above elementary grades), of government, and of communication with those outside of the region.

Within Austronesian, the relevant subgrouping relationships of Hainan Cham are straightforward (Thurgood 1999). Of particular interest to the concerns here is the fact that, despite the typological similarity of Northern Roglai to the other Chamic languages of the mainland, Northern Roglai subgroups most closely with the Hainan Cham, not the other mainland languages: Both share two rather distinctive sound changes: the loss of the word-final Proto-Chamic *-s after

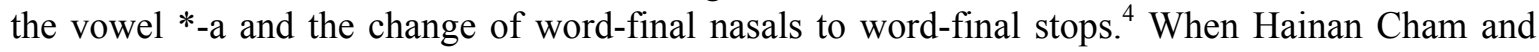
Northern Roglai differ, it is usually easy to establish that Northern Roglai patterns with the rest of

${ }^{2}$ The population figures are from Brunelle (2008a:29-30), who discusses the various numbers available and their reliability.

${ }^{3}$ The centrality of these considerations is not restricted to just these languages, of course. Other languages that seem to have particular relevance to this discussion include the Malay of Nonthaburi (Tadmor 1995), Baba Malay (Thurgood 1998), Jiamao (Thurgood 1992), various Malay dialects, etc.

${ }^{4}$ See Thurgood (1999:224ff) for a more detailed discussion. 
Chamic (and, usually, with wider Austronesian). Of course, it goes without saying that each instance needs to be examined on its own merits.

Hainan Cham split off from Northern Roglai around 982, migrating to Hainan, with a second migration of Chamic speakers joining this first group around 1471. Work has been done on genetic affiliations of Hainan Cham (Benedict 1941), the history of the Chamic languages including Hainan Cham (e.g. Thurgood 1999, 1996), and on the description of Hainan Cham itself (Ouyang \& Zheng 1983; Zheng 1986, 1997) with the later work by Zheng (1997) including numerous valuable observations on the influence of Chinese on Hainan Cham, both identifying Chinese borrowings and commenting on Chinese structural influence.

Two migrations of Chamic speakers can be dated with confidence. The first migration involves what the literature on the Champa Kingdom calls the Northern Cham, Chamic speakers originally located around Indrapura (Figure 1).

\section{Figure 1: The Northern and Southern capitals of Champa}

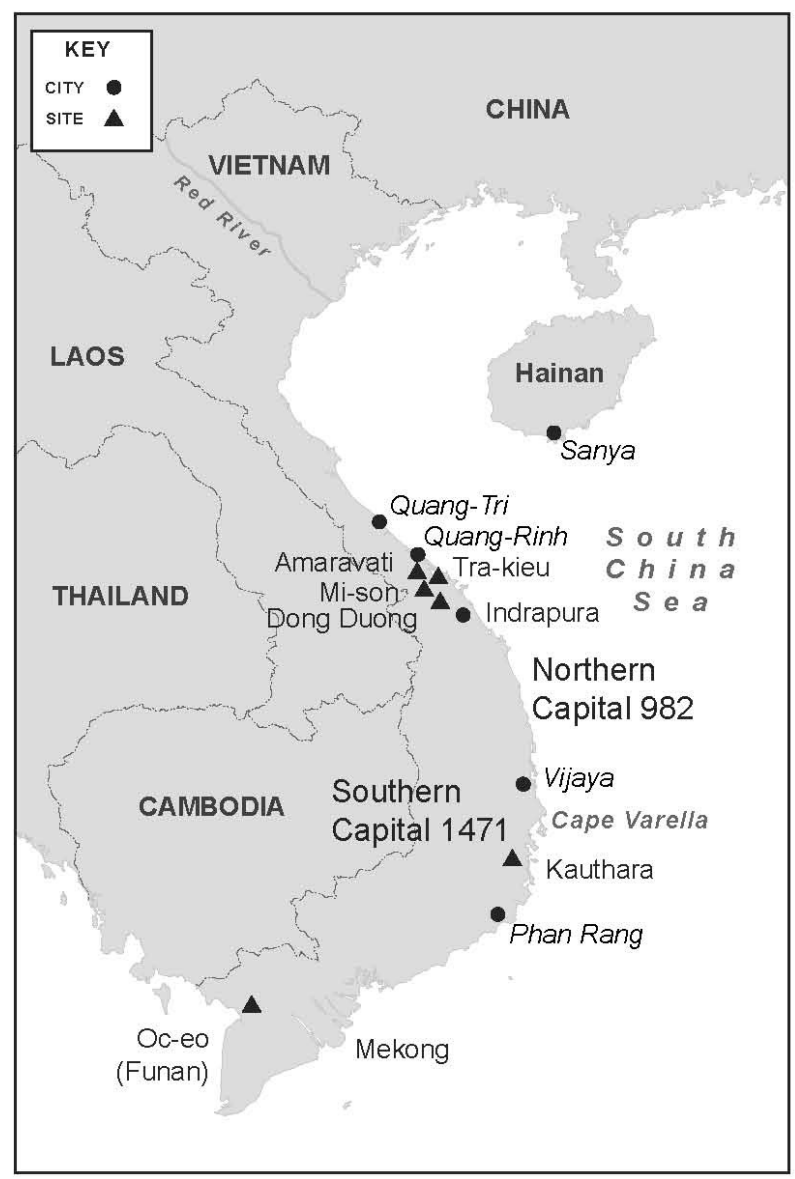

The linguistic record makes it clear that the modern Hainan Cham, found near Sanya City, and the Northern Roglai, now found in southern Vietnam, were once the same group. ${ }^{5}$ However, one part of the group is now on Hainan Island and the other part is now inland in southern Vietnam; the

${ }^{5}$ The Acehnese were not part of this Northern Cham group, as Acehnese does not have either of the two shared innovations that characterize the Northern Cham group. 
modern distribution only makes sense if they both descend from the Northern Cham, that is, the northern part of the Champa kingdom, with the merchants fleeing to Hainan and the non-merchant class moving south with the fall of the northern capital. This scenario also explains why the Northern Roglai are reputed to have had in their position some of the royal regalia from the kingdom of Champa - when the northern capital fell, it was the royal capital. In addition, the Chinese dynastic records date the arrival of the Hainan Cham. The northern capital of Champa, Indrapura, fell in 982, splitting the Northern Cham into two, with those engaged in trading migrating to the southern tip of Hainan Island while the remaining Northern Cham, most of those engaged in farming, crafts, and the like, migrated south. The Chinese records show these refugees arriving in Hainan and paying tribute to the Chinese just four years after the fall of Indrapura. ${ }^{6}$

The second migration that can be dependably dated correlates with the fall of the southern capital in 1471 (Figure 1). ${ }^{7}$ It is also undoubtedly the same migration from Champa referred to in the Sejarah Melayu, which reports two sons of the king of Champa fleeing from Champa along with many others, including wives and children (Shellabear 1909:110). The date 1471 fits remarkably well with the earliest date recorded for the Aceh dynasty, a date which is found on a Chinese bell (Reid 2006:10). This bell, which Reid describes as "part of the regalia of the Aceh kingdom," has inscriptions in Arabic/Persian and in Chinese. The Chinese date (Reid 2006:10, and fn. 33) is equivalent to late 1469 or January $1470 .{ }^{8}$ Not only does the date on the bell fit with the 1471 date of the fall of the southern capital Vijiaya, but the linguistic fit is just as close: the linguistic evidence shows that at the time Acehnese split from the other Chamic languages, it was largely undifferentiated from the other Chamic dialects. As Durie (1990:111) notes, Acehnese does not share features consistently with any single group of Chamic languages; ${ }^{9}$ my own examination also concludes that the separation of Acehnese from the rest of Chamic predates the breakup of the Chamic group. ${ }^{10}$

Despite the genetic closeness, Hainan Cham is now radically different both phonologically and syntactically from Northern Roglai. Phonologically, Northern Roglai is sesquisyllabic and atonal whereas Hainan Cham is monosyllabic and fully tonal. Structurally, Northern Roglai is much, much more like the other Chamic languages of Vietnam, while Hainan Cham, not surprisingly, is much like the Chinese dialects and the Tai-Kadai dialects that surround it. Increasingly, all that remains of Hainan Cham is the vocabulary, with the structure being Chinese, albeit with Hainan Cham lexical items. Of interest here, Hainan Cham provides some exceptionally clear examples of contact-induced syntactic variation and change.

${ }^{6}$ The Chinese record a second and apparently smaller group of Chamic speakers as arriving in Hainan in 1486.

7 The most phonologically distinctive of the Chamic languages, Hainan Cham, migrated to Hainan in two waves, the first in 986 after the fall of the northern capital and the second in 1486 after the fall of the southern capital. Its differentiation from the rest of the Chamic languages

${ }^{8}$ Reid (2006:20) notes in an endnote that there is a widespread missing reading of the date as 1409 which was subsequently corrected to $1469-70$ by Wolfgang Franke (1988:44).

${ }^{9}$ It has been speculated that Acehnese and the rest of Chamic are sisters to each other, but no linguistic evidence has been presented to support this position. Methodologically, there is no reason to split it off; Acehnese is more conservative than the mainland dialects but one would expect that mainland dialects to be less conservative (far longer and more intense contact with Mon-Khmer) and there is no evidence of shared innovations that indicate a split.

${ }^{10}$ I would certainly speculate that there at least some Cham speakers already in northern Sumatra when this migration arrived, but the large influx of people would most likely have significantly changed the balance of power in the region and the linguistic composition. 


\subsection{Contact-induced restructuring}

Changes in Hainan Cham resulting from contact with neighbouring languages of Hainan are quite obvious. Phonologically, Hainan Cham has gone from sesquisyllabic and registral to monosyllabic and tonal. Lexically, it contains words reflecting contact with various languages found on Hainan: Hlai language (= Li; a subgroup of Tai-Kadai, the family that includes Thai), contact with an early Cantonese dialect (probably Mai), substantial contact with a dialect of Southwest Mandarin (so-called 'military speech') spoken by the army and government officials, contact with Hainanese Chinese, a Min dialect spoken on the island; and, contact with the Mandarin of the schools and the government.

\subsubsection{Phonology}

There were two major adjustments, mediated by contact, to the word structure. The first was towards monosyllabicity, a change that started before the breakup of Proto-Chamic but culminating in the monosyllables of Hainan Cham. The second was the development of tones, occurring after the Hainan Cham had arrived in Hainan.

Monosyllabicity. When the language that was to become Proto-Chamic arrived on what is now the coast of Vietnam, it was largely disyllabic and atonal, with penultimate stress except unless the penultimate vowel was schwa; in that case, stress fell on the final syllable. The Mon-Khmer languages (probably Bahnaric; Sidwell, p.c., 2007, 2008) along the Vietnamese coast were sesquisyllabic with final stress; in contact with these languages, pre-Proto-Chamic likewise developed final stress. Even today most Chamic languages are sesquisyllabic with final stress, as is, for example, Northern Roglai. The movement to final stress had consequences for the roots.

Sesquisyllabic words with medial *-h- lost the weakly stressed vowel in the onset syllable, becoming monosyllabic at the Proto-Chamic level, as shown in Table 1. The first column is ProtoAustronesian (PAn), the second is Malay (a representative of the Malayic side of Malayo-Chamic), the third is Proto-Chamic, the fourth is Written Chamic, and the fifth is Hainan Cham.

Table 1. From disyllables with medial *-h- to monosyllables.

\begin{tabular}{|c|c|c|c|c|c|}
\hline$P A n$ & Malay & $P C$ & Wr. Cham & Hainan Cham & \\
\hline *daqiS & dahi & *dhə̃i & dhei & thai $^{33}$ & 'forehead' \\
\hline *puqun & pohon & *phŭn & phun & phun $^{33}$ & 'plant' \\
\hline *paqit & pahit & *phĩ? & --- & phi? ${ }^{2^{4}}$ & 'bitter' \\
\hline *paqat & pahat & *pha:t & pha? & pha? $2^{2^{4}}$ & 'chisel' \\
\hline *paqa & paha & *pha & phā & pha $^{33}$ & 'leg, thigh' \\
\hline *taqun & tahun & *thŭn & thun & thun ${ }^{33}$ & 'year' \\
\hline
\end{tabular}

Under the external influence of contact with the monosyllabic languages of Hainan and under the internal impetus of final stress, the medial liquids followed a similar path, see Table 2. In Hainan Cham, the weakened unstressed vowel in the onset syllable first dropped producing onset clusters with liquids in second position and then the liquids became $-i$ - glides.

Table 2. From disyllables with medial liquids to monosyllables.

$\begin{array}{lllllll}\text { PAn } & \text { PC } & \text { Wr. Cham } & \text { Chru } & \text { N. Roglai } & \text { Hainan Cham } & \\ \text { *daRaq } & \text { *darah } & \text { darah } & \text { drah } & \text { darah } & \text { sia } & \text { 'blood' } \\ \text { *bulu } & \text { *biləu } & \text { bulău } & \text { bləu } & \text { biləu } & \text { phiə } & \text { 'body hair' } \\ \text { *qabaRa } & \text { *bara } & \text { bara } & \text { bra } & \text { bara } & \text { phia }{ }^{11} & \text { 'shoulder' } \\ \text { *bulan } & \text { *bula:n } & \text { bulan } & \text { bla:n } & \text { bilã:t } & \text { phian }{ }^{11} & \text { 'moon' }\end{array}$


The remaining Hainan Cham disyllabic words simply dropped the whole first syllable, see Table 3. Presumably, the weakened unstressed vowel in the onset syllable reduced until the form consisted of a monosyllable with a consonantal cluster and then the initial consonant in the cluster dropped, leaving a structure matching that of the languages of Hainan.

Table 3. From other disyllables to monosyllables.

\begin{tabular}{|c|c|c|c|c|c|c|}
\hline PAn & $\mathrm{PC}$ & Wr. Cham & Chru & N. Roglai & Hainan Cham & \\
\hline *lapaR & *lapa & lapa & ləpa & lapa & $\mathrm{pa}^{33}$ & 'hungry' \\
\hline *mamaq & *mumãh & memeh & bəmah & mumãh & $\mathrm{ma}^{55}$ & 'chew' \\
\hline *pajay & *paday & padai & pədai & padai & tha: $i ?^{4_{2}}$ & 'rice (paddy)' \\
\hline *quzan & *huja:n & hujan & həjañ & huja:t & $\mathrm{sa}: \mathrm{n}^{11}$ & 'rain' \\
\hline$*$ taliS & *taləi & talei & tələi & taləi & $1 a i^{33}$ & 'rope; string' \\
\hline *tayan & *tana:n & tanin & tə⿹аñ & tayãn & ya: $n^{33}$ & 'hand' \\
\hline *lima & *lima & limə & ləma & lumã & $\mathrm{ma}^{33}$ & 'five' \\
\hline$*_{\mathrm{m}}$-uda & $*_{\text {muda }}$ & medā & məda & mida & tha ${ }^{11}$ & 'young; unripe' \\
\hline *baseq & *basah & basah & pəsah & pasha & $\mathrm{sa}^{55}$ & 'wet; damp' \\
\hline *qumah & *huma & humā & həma & humã & $\mathrm{ma}^{33}$ & 'dry field' \\
\hline
\end{tabular}

Development of tones. The external cause of the development of Hainan Cham tones is contact with the tone languages of the island; not only was Hainan Cham in intimate contact with a Mandarin dialect spoken in Sanya, as is evident from a large number of loans from that dialect into Hainan Cham, but Hainan Cham speakers also speak other tonal languages of the island. Internally, the path of development of Hainan Cham's rich, 5-way tonal system has been of considerable theoretical interest since the Hainan Cham case is one of the best illustrations of the development of a fully tonal system from an atonal system (Haudricourt 1984, Benedict 1984, Maddieson \& Pang 1993, Ni 1988ab, 1990ab, Thurgood 1993, 1996, 1999, Thurgood \& Thurgood 2005 (instrumental)). ${ }^{11}$

The internal path is straightforward: The modern Hainan Cham tones are predictable from the voicing differences in the earlier initials and finals, with laryngeal settings being the source of tonogenesis. The tones themselves are marked with Zhao [Chao] tone numbers. The numbers indicate relative pitch height, with 5 being high, 3 in the middle, and 1 low. The first number indicates where the tone begins; the second where the tone ends. Thus, for example, 55 is a high, level tone.

The 55 tone evolves from a final *-h, regardless of the initials involved. Final *-h represents, of course, a laryngeal adjustment. For examples, see Table 4.

Table 4. Tone 55 from PC *-h $(<P A n *-q)$.

$\begin{array}{llllll}\text { PAn } & \text { Malay } & \text { PC } & \text { N. Roglai } & \text { Hainan Cham } & \\ \text { *putus } & \text { pecah } & \text { *picah } & --- & \text { tsa }^{55} & \text { 'broken; break' } \\ \text { *puluq } & \text { puluh } & \text { *pluh } & \text { pluh } & \text { piu }^{55} & \text { 'ten' } \\ \text { *taneq } & \text { tanah } & \text { *tanah } & \text { tanãh } & \mathrm{na}^{55} & \text { 'earth, soil' } \\ \text { *panaq } & \text { panah } & \text { *panah } & \text { panãh } & \mathrm{na}^{55} & \text { '(shoot) bow' } \\ \text { *ma-iRaq } & \text { merah } & \text { *mahirah } & \text { meriah } & \mathrm{za}^{55} & \text { 'red' } \\ \text { *belaq } & \text { belah } & \text { *blah } & \text { blah } & \text { phia }^{55} & \text { 'chop; split' } \\ \text { *nanaq } & \text { nanah } & \text { *lanah } & \text { lanãh } & \text { lə }^{11} \mathrm{na}^{55} & \text { 'pus' }\end{array}$

${ }^{11}$ One of the changes in Hainan Cham is the addition of a final glottal stop to forms ending in -ay and -aw. Ross (2003:180-181) follows Andersen (1988) in suggesting that such changes such as these epenthetic final glottals stops may be restricted to linguistically closed communities; in the case of Hainan Cham, the language is certainly closed, being spoken only by the Hainan Cham. 
*buaq buah *bauh boh pho 'fruit, clf.'

The remaining tones split the lexicon into two groups-words with high-pitched, modal 'normal' phonation and words with a low-pitched, breathy-voiced phonation. The breathy phonation developed out of the voiced obstruents. The tones of words with final nasals or vowels had a 11 tone, if the initial consonant of the main syllable in the PC form was a voiced obstruent; comparison with other Chamic languages suggests that the voiced obstruent led to breathiness on the vowel - a laryngeal adjustment - which produced this low tone. With an exception discussed below, if the initial consonant of main syllable was not a voiced obstruent, the tone was 33-the default tone, that is, there was no change in the laryngeal configuration.

\section{Table 5. Words with vowel or nasal-final codas.}

\begin{tabular}{|c|c|c|c|c|c|}
\hline$P A n$ & Malay & $P C$ & N. Roglai & Hainan Cham & \\
\hline --- & dua & $*$ dua & dua & thua $^{11}$ & 'two' \\
\hline --- & hiduy & *Pidŭn & idũk & thuy $^{11}$ & 'nose' \\
\hline --- & kerbau & *kubaw & kabau & pha: $u^{11}$ & 'water buffalo' \\
\hline --- & $\mathrm{abu}$ & *habəu & habəu & phə ${ }^{11}$ & 'ashes' \\
\hline --- & ubi & *hubəi & habuəi & phai $^{11}$ & 'taro; yam' \\
\hline --- & hujan & *huja:n & huja:t & $\mathrm{sa}: \mathrm{n}^{11}$ & 'rain' \\
\hline --- & dada & *dada & dada & tha ${ }^{11}$ & 'chest' \\
\hline *qudip & gigi & *digəi & digəi & $\mathrm{xai}^{11}$ & 'tooth' \\
\hline *babuy & babi & *babuy & babui & phui $^{11}$ & 'wild pig' \\
\hline *ulaR & ular & *?ula & ula & $1 a^{33}$ & 'snake' \\
\hline *telen & telan & *lu:n & luət & $\operatorname{luan}^{33}$ & 'to swallow' \\
\hline *taqun & tahun & *thŭn & thut & thun $^{33}$ & 'year' \\
\hline *tayan & tayan & *tana:n & tạãn & ya:n $n^{33}$ & 'hand' \\
\hline *qumah & huma & *huma & humã & $\mathrm{ma}^{33}$ & 'dry field' \\
\hline *puqun & pohon & *phŭn & phut & phun $^{33}$ & 'trunk; plant' \\
\hline *lima & $\operatorname{lima}$ & *lima & limã & $\mathrm{ma}^{33}$ & 'five' \\
\hline *kaSiw & kayu & *kayəu & kayəu & $\mathrm{zau}^{33}$ & 'tree; wood' \\
\hline *Sapuy & api & *?apuy & apui & pui $^{33}$ & 'fire' \\
\hline *enem & enam & *năm & nãm & nan $P^{33}$ & 'six’' \\
\hline
\end{tabular}

The tones of words with final stop codas behaved in a parallel way. Final stops turned into final glottal stops - a laryngeal adjustment. If the initial consonant of the main syllable in the PC form was a voiced obstruent, the voiced obstruent led to breathiness on the vowel, producing a 42 stopped tone. With an exception discussed below, if the initial consonant of main syllable was not a voiced obstruent, the tone was 24 stopped tone-the default tone. The PC final nasals and glides that developed final glottal stops pattern with these stop final words. 
Table 6. Words with final stop codas.

\begin{tabular}{|c|c|c|c|c|c|}
\hline$P A n$ & Malay & $P C$ & N. Roglai & Hainan Cham & \\
\hline --- & --- & *brŭa? & brũk & phua? ${ }^{4_{2} S}$ & 'work' \\
\hline --- & --- & $*$ dadit & dadi:t & thi? $?^{4_{2} S}$ & 'a fan' \\
\hline--- & duduk & $* \mathrm{do}: \mathrm{k}$ & do:? & tho? $?^{4_{2 S}}$ & 'sit; live; stay' \\
\hline --- & hidup & *hadip & hadiu? & thiu? $?^{4_{2} S}$ & 'live, alive' \\
\hline *anak & anak & *?ana:k & anã:? & $\operatorname{naP}^{24} \mathrm{~s}$ & 'child' \\
\hline *sakit & sakit & *saki? & saki:? & $\mathrm{ki}^{22^{4} \mathrm{~S}}$ & 'sick, painful' \\
\hline *hiket & ikat & *?ikă? & ika? & $\mathrm{kaP}^{24 \mathrm{~s}}$ & 'to tie' \\
\hline *lanit & lanit & *lani:? & lanĩ:? & $\mathrm{yi}^{22^{4} \mathrm{~S}}$ & ‘sky’ \\
\hline *Sepat & empat & *pa:? & pa:? & $\mathrm{paP}^{24 \mathrm{~s}}$ & 'four' \\
\hline *paqat & pahat & *pha:t & --- & pha $2^{24} \mathrm{~s}$ & 'chisel' \\
\hline *uRat & urat & *?urăt & ura? & $\mathrm{za}^{22^{4} \mathrm{~s}}$ & 'vein, tendon' \\
\hline
\end{tabular}

Finally, there are disyllabic forms in which it was not the main syllable initial but the initial of the first syllable that determined the final tone. First syllable voiced obstruents produced breathiness and if the second syllable initial was a sonorant, ${ }^{*} \mathrm{~s},{ }^{*} \mathrm{~h}$, or a voiceless stop, the breathiness spread from the first syllable to the second syllable, thereby determining the tone class of the second syllable. Note that each Hainan Cham tone shows evidence of the earlier PC initial voiced obstruent.

Table 7. Breathiness spreading through medial sonorants, *s \& *h, and voiceless stops.

\begin{tabular}{|c|c|c|c|c|c|}
\hline $\begin{array}{l}P A n \\
\text { *-- } \\
\text { *baqeRu }\end{array}$ & $\begin{array}{l}\text { Malay } \\
--- \\
\text { baharu }\end{array}$ & $\begin{array}{l}P C \\
\text { *bisəi } \\
\text { *bahrəu }\end{array}$ & $\begin{array}{l}\text { N. Roglai } \\
\text { pisəi } \\
\text { bahrəu }\end{array}$ & $\begin{array}{l}\text { Hainan Cham } \\
\text { sai }^{11} \\
\text { phij }^{11}\end{array}$ & $\begin{array}{l}\text { 'iron' } \\
\text { 'new' }\end{array}$ \\
\hline --- & batuk & *bitŭk & pitu? & $\operatorname{tu}^{4_{2} \mathrm{~S}}$ & 'cough' \\
\hline *dikit & dikit & $*$ diki? & tiki:? & $k i P^{4_{2} S}$ & 'few; little' \\
\hline *batu & batu & *batəu & patəu & $\operatorname{tau}^{11}$ & 'stone' \\
\hline --- & --- & *bato & pato & to $^{11}$ & 'teach' \\
\hline--- & --- & *bitəi & pitəi & $\mathrm{u}^{11} \operatorname{tai}^{11}$ & 'banana' \\
\hline depa & depa & *dupa & tupa & $\mathrm{pa}^{11}$ & 'armspan' \\
\hline
\end{tabular}

The significance of both the development of monosyllabicity and tones in Hainan Cham is that it was under contact with monosyllabic, tonal languages that the changes occurred. Exactly the same internal conditions but with different contact patterns produced other outcomes in the Chamic languages of the mainland. 


\subsubsection{Lexicon}

The Hainan Cham lexicon shows several discernible layers of borrowings: a Mon-Khmer layer (overwhelmingly Bahnaric (P. Sidwell, p.c.; 2007, 2008)) dating back in part to Proto-Chamic (c. 750 items). ${ }^{12}$ There are four sources of Chinese items: a small, earlier one looking like it was a Min dialect (possibly Mai), a later Southwest Mandarin layer, reflecting both earlier contact with the socalled Military language; contact with the Hainanese Chinese spoken on Hainan, and, the current contact with standard Mandarin. In addition, there are occasional bits and pieces of Li and other languages (cf. Thurgood 1999).

The Chinese borrowings include a full range of items: content words, classifiers, numbers, ${ }^{13}$ prepositions, adverbs, verbs, nouns, conjunctions, and so on. Zheng (1997) comments on the pervasiveness of Chinese loans, which was undoubtedly obvious to her upon inspection. Based on my own etymologies and counts, there are roughly 600 borrowings from Chinese $(30 \%$ of the lexicon): 236 of the nouns are borrowed (that is, $30.6 \%$ of the nouns are borrowed from Chinese), 158 of the verbs $(25.3 \%), 63$ of the adjectives ${ }^{14}(25.6 \%), 48$ of the adverbs $(47.5 \%), 18$ of the conjunctions (78\%), 11 of the prepositions $(42.3 \%), 29$ of the sortal classifiers $(78 \%)$, and 15 of the mensural (measure) classifiers (55.6\%).

\subsubsection{Grammar}

While the phonological restructuring of Hainan Cham has been written about extensively elsewhere, its structural changes are less well-known. These are widely attested in Hainan Cham, sometimes with a grammatical marker from Chinese in the borrowed structure. This restructuring has also been discussed elsewhere (cf. Thurgood \& Li 2003a).

Thurgood \& Li (2003a) note the co-existence of constructions with alternate word orders, one inherited and one Sinicized. Although both the Chamic languages and Chinese share a basic SVO word order, the two differ in patterns of nominal modification: the Chamic languages favour posthead modification, while Chinese favours prehead. In the alternations in the Thurgood \& Li study (2003a), the older, inherited pattern was post-head modification, and the more recently-innovated pattern paralleled Chinese. There are two major pieces of evidence for this: One is that the prehead patterns do not occur in Northern Roglai-the Chamic language genetically-closest to Hainan Cham, nor do they occur in any of the other Chamic languages for which we have data. Two, the prehead patterns are virtually word-by-word calques of structures in Mandarin Chinese.

The genitive patterns with full noun phrases differ from those with pronouns. In Northern Roglai, full-NP genitives are postposed, but in Hainan Cham, all full-NP genitives are preposed with the genitive construction marked by $s a^{33}$, even in the most colloquial ${ }^{15}$, least Sinicized texts

\footnotetext{
${ }^{12}$ After the formation of Proto-Chamic, Common Chamic may have lasted as a largely undifferentiated dialect chain for long as a thousand years before subsequently breaking up into distinct dialects. Thus, it is often difficult to determine with any precision when various Mon-Khmer loans came into the language. The problem is confounded by the fact that the written records of the time probably represent a register significantly different than the spoken register.

${ }^{13}$ Numbers show a different pattern. The cardinal numbers are inherited, but in certain contexts a set of cardinals borrowed from Chinese is used, especially, for example, in dates. The ordinal marker is borrowed from Chinese. The grammar of fractions is Chinese, but the numbers themselves are inherited.

${ }^{14}$ If the adjectives were treated as intransitive verbs, which they could be in Hainan Cham, the numbers would be the same but with different labels.

${ }^{15}$ The term 'colloquial' is being used loosely to refer to the texts that tell folktales or stories about the Hainan Cham. The contrast is with texts that discuss, for example, Third Session of the Eleventh Plenary Meeting of the Communist Party, which contain not just far more loanwords but also patterns that do not appear elsewhere in our database. These we have termed 'Sinicized'.
} 
(Thurgood \& Li 2003a:187). The more Mandarinized variants tend to occur in more Mandarinized texts, sometimes along with borrowed Mandarin grammatical markers and the word order borrowed. ${ }^{16}$ The Hainan Cham genitives with pronouns, however, show both the older postposed pattern and a newer preposed pattern. In Northern Roglai (and mainland Chamic), genitives with pronouns are postposed, but in Hainan Cham both postposed and preposed genitives occur, with the preposed pronouns genitives marked by $s a^{33}$ again even in the most colloquial, least Sinicized texts.

The demonstrative pronouns show a pattern similar to that of the genitive pronouns: in Northern Roglai demonstratives are postposed; in colloquial Hainan Cham they remain postposed, but in Chinese-influenced Hainan Cham, as in Mandarin, they are preposed. In addition, in Chineseinfluenced Hainan Cham, the demonstratives are often accompanied by the genitive marker $s a^{33}$, a pattern paralleling the Mandarin construction. The demonstrative-noun order is a result of Chinese contact. This word order change, induced by extensive and prolonged contact with Chinese, is quite systematic and pervasive throughout the grammatical system of Hainan Cham. It is found in texts collected from the same speaker by Zheng Yiqing in the 1980s and published in Zheng (1997). It is interesting to note that the borrowed patterns are found in texts that describe more politicallyinfluenced phenomena, whereas the native patterns are used in texts of traditional stories.

With adjectives, the colloquial Hainan Cham retains the postposed position for adjectives found in closely related Northern Roglai, while the Mandarinized Hainan Cham, like Mandarin, has preposed adjectives (Thurgood \& Li 2003a:191-192). Under the influence of Chinese, preposed modifiers of a head noun are often accompanied by a genitive marker.

In comparatives, the existence of an inherited and a contact-induced Mandarin-influenced word order is quite clear. As Zheng (1997:75) writes, the word order for the inherited pattern is qualitymarker-standard (X - Adj - CM / ST), that is, the quality being compared, followed by la:w ${ }^{32}$ ' $\mathrm{CM}$; pass, exceed', a preposition derived from a verb (Thurgood \& Li 2003a:193-195). For example,

Hainan Cham (colloquial):

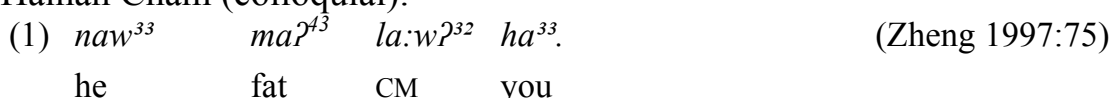

'He is fatter than you.'

(2) $l u^{33}$

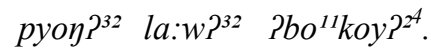

(Zheng 1997:89)

coconut.palm big $\mathrm{CM}$ pomelo

'The coconut palm is bigger than the pomelo.'

(3) Pal $^{11} k o^{33} \quad p^{h} a y P^{43} \quad k^{h} a: n P^{21} \quad n a: y P^{32} \quad l a: w P^{32}$ Path $a y^{11}$. (Zheng 1997:75)

elder.bro read book good CM young.bro

'Elder brother studies more than younger brother.'

Zheng then compares the inherited comparative pattern with the pattern associated with Mandarin influence, as is obvious not just by the word order but also by its use of the borrowed comparative marker $p i^{11}$ ' $\mathrm{CM}$; compare'.

\footnotetext{
${ }^{16}$ At times it is the borrowed Mandarin grammatical marker that marks the construction, hence, in essence, it
} is a construction that was borrowed. 
$\begin{array}{lllllll}\text { (4) } k_{a w^{33}} & p i^{11} & h a^{33} & \text { tsat }^{24} t O^{33} & k i \gamma^{33} & \operatorname{sun}^{33} . & \text { (Zheng 1997:75) } \\ \text { I } & \text { CM } & \text { you } & \text { short } & \text { three } & \text { inch } & \end{array}$

'I am three inches shorter than you.'

(5) $m i^{33}$

we

'...our life went downhill each day,'

(6)

$\begin{array}{llll}\text { zin }^{11} \min ^{11} & \text { sa }^{33} & \operatorname{sa\eta }^{33} h u a t^{2^{4}} & \operatorname{ta}^{11} \mathrm{zay}^{33} \mathrm{pir}^{43} \\ \text { people } & \text { GEN } & \text { life } & \text { one.day CM }\end{array}$

$\operatorname{ta}^{11} z a y^{33} \mathrm{pi}^{4{ }^{4}}$

one.day $\mathrm{CM}$

${ }^{1 a^{11} z a y^{33}} \mathrm{pu}^{33}$

na:y P $^{32}$,

(Zheng 1997:2.1.4)

one.day NEG

good

'...people's lives began to get better and better.'

Numerous other non-varying structural patterns are also heavily Chinese influenced. Most of the adverbs, prepositions, and conjunctions are borrowed from Chinese, a phenomenon not uncommon in Southeast Asian contact situations. When this happens, whether in Hainan Cham or elsewhere, it is usually the form and its syntax that is borrowed, not just the form - in short, it is a structural pattern, not a word, that is borrowed, a structural pattern marked by a defining morpheme.

\subsection{Language contact patterns}

Up from the 4131 of the 1982 census, the 1990 census shows that there are roughly 5695 Hainan Cham $^{17}$ in Hainan Province, with Zheng estimating that 5000 or so of these reside in Sanya. In the 1980s when Zheng and Ouyang began their work on Hainan Cham, the villages of Huihui and the Huixin were both surrounded by villages that speak several distinct dialects of Chinese and Hlai (= Li). Zheng and Ouyang characterized the Chinese dialect spoken then by the Hainan Cham as a variety of 'military speech', ${ }^{18}$ that is, Southwest Mandarin, but a variety quite distinct both from the military speech in Yacheng and the military speech of Basuo in Dongfang County, a variety that is disappearing among the Hainan Cham. It is, without question, this now moribund dialect that left the greatest impact on the phonology, lexicon, and grammar of Hainan Cham — and, it is this dialect for which we have the least direct evidence. ${ }^{19}$

The villagers in Huihui and Huixin can all speak their native language Hainan Cham fluently. ${ }^{20}$ The adults have quite high literacy skills in Chinese. Most of the adults, including women, speak several Chinese dialects, and a small number of people also speak Li. In old Yacheng City and its vicinity as well as for several dozen miles west of Huihui and Huixin, varieties of the so-called military speech (the official language of the southwest among the northern Chinese dialects) are spoken. In Yanglan Village to the northeast, two Min dialects, both closely related to Cantonese, are spoken: the Mai dialect and the Danzhou dialect, spoken in Haipo Village in the south, which is the same dialect as the dialect spoken in Danzhou in Dan Country in the northern part of the island. From the east to the west along the seashore, the Hainan dialect (a Taiwanese dialect) is used. In Sanya City itself one sometimes finds speakers of Mandarin Chinese and Cantonese.

\footnotetext{
${ }^{17}$ More precisely, the census states that there are that many hui 'Muslim' in the area, but since the vast majority of the Muslims in the area are Hainan Cham, the census figures provide a reasonably close estimate of the number of Hainan Cham.

${ }^{18}$ Careful examination of the 250 or so forms supplied in Zheng and comparison of these with the Chinese borrowings in Hainan Cham makes it clear that this Sanya Cham Chinese is Southwest Mandarin and that it is this dialect that was the source of early Chinese that was the early dominant influence on Hainan Cham.

${ }^{19}$ What we have is a very valuable lexicon of about 300 words.

${ }^{20}$ The domains of usage, however, are restricted to use in the home and village. Other languages are used for business, school (beyond elementary), and government.
} 
In 1984, Yiqing Zheng, Kerang Tan, Guanghua Xie, and Jiquan Wang went to Yanglan Township of Sanya Municipality and did a language survey of 76 people, aged 6 or older. The results are presented along with discussion in Zheng (1997:14-18, Table 8), which shows the languages, number of speakers, and age ranges for the 76 fluent Cham speakers surveyed (Zheng 1999:14-18).

Table 8: Ages, languages spoken, and numbers of speakers $F=$ fluent, $C=$ comprehend.

\begin{tabular}{|c|c|c|c|c|c|c|c|c|c|}
\hline \multirow[t]{2}{*}{ Ages } & \multirow{2}{*}{$\begin{array}{l}\text { Cham } \\
\text { F }\end{array}$} & \multicolumn{2}{|c|}{ Mandarin } & \multicolumn{2}{|c|}{ Hainanese } & \multirow{2}{*}{$\begin{array}{l}\text { Mai } \\
\text { F }\end{array}$} & \multirow[b]{2}{*}{$\mathrm{C}$} & \multirow{2}{*}{$\frac{\mathrm{Li}}{\mathrm{F}}$} & \multirow[b]{2}{*}{$\mathrm{C}$} \\
\hline & & $\mathrm{F}$ & $\mathrm{C}$ & F & $\mathrm{C}$ & & & & \\
\hline $7-12$ & 5 & 2 & 2 & & 4 & & & & \\
\hline $13-17$ & 10 & 8 & 2 & 8 & 1 & 3 & 1 & 1 & \\
\hline $18-45$ & 43 & 37 & 6 & 42 & 1 & 18 & 10 & 6 & 9 \\
\hline $46-59$ & 11 & 4 & 5 & 9 & 1 & 11 & & 6 & 3 \\
\hline $60+$ & 7 & 4 & 1 & 6 & 1 & 6 & 1 & 4 & 1 \\
\hline Total & 76 & 55 & 16 & 65 & 8 & 38 & 12 & 17 & 13 \\
\hline
\end{tabular}

Mandarin. Of the total number of people surveyed, 55 are proficient in Mandarin Chinese (i.e. $72 \%$ ) and 16 have some comprehension of Mandarin Chinese, making it 93\% who either speak or comprehend Mandarin. Those with only some comprehension of Mandarin Chinese are either young children or middle-aged or older; otherwise, they would have been learned it in school. In the village, the young people speak Cham first, learn Mandarin in school, and then pick up Hainanese Chinese. Earlier, many Cham knew the so-called military dialect, but that has been superseded by Mandarin.

Hainanese Chinese. Of the Hainan Cham surveyed, all of them except those under 14 speak Hainanese $(86 \%)$ or at least comprehend it (8); school children do not have much opportunity to interact with Hainanese Chinese speakers.

The Mai dialect. Of the 76 people surveyed, 38 speak Mai with 12 more having some comprehension, amounting to $65 \%$ of the total surveyed. This high percentage is because about a kilometre away from Huihui village lies a high school in Yanglan village, where many of the Cham went to high school and where many of the students speak Mai. In addition, the Mai dialect is commonly used in market places. As a result, many of those who are 16 or older, male or female, know some Mai.

The Li dialects. Some 39\% of the Cham, most of them older, know some Li. These people all have extensive interactions with the Li people. 
Others. In addition to the these languages included in the table, some of the Cham speakers also speak the Danzhou dialect (8) - a Cantonese dialect, Cantonese (4), the Military dialect (2), and Japanese (3). Specific circumstances led to the learning of these languages; they are not in typical daily use.

Which language the Cham speakers use is situationally determined. In Huihui and Huixin villages, Cham is used as the major language of communication, but even within the village often there is a switch to Mandarin (government, school, linguistic subjects); unless speaking to a fellow Cham, another language is used outside the village; Mandarin for government matters or to outsiders or sometimes Hainanese Chinese to local people or for business. At the elementary school, Mandarin is used in the classroom, but when explaining school texts, Cham is also used. When intellectuals and cadres interact with visitors from the mainland, Mandarin Chinese is used for the most part. For instance, during our fieldwork, whenever the Cham were discussing the language among themselves, Mandarin was used by all six of our informants, in part because it was the closest thing to a common language for those in the room but also in part because for this topic it was their best language. With some frequency, elicitation produced a Mandarin form (or, much less commonly a Hainanese form), leading to a discussion of what the Cham form was. The general public can also use Mandarin Chinese to communicate with mainlanders. When they interact with the Hainanese Chinese dialect speakers from within Hainan Province, they use Hainanese Chinese, though youngsters, having gone through public schools, generally use Mandarin Chinese. Not many of the younger speakers can communicate in $\mathrm{Li}$ when interacting with the $\mathrm{Li}$, so the Hainanese dialect or Mandarin is often used. In the market place and within the Sanya Municipality, the Cham speakers use Cham among themselves, and when the older speakers interact with Hainanese who are speakers of other languages, they mostly use Hainanese Chinese. However, in the market places near the government seat of Yanglan Township, they either use the Hainanese dialect of Chinese or the Mai dialect of Chinese.

While Hainan Cham is still spoken as in the village, even between two Hainan Cham speakers the growing dominance of Chinese is fairly obvious. As noted above, for an increasing range of topics, the Hainan Cham feel more comfortable in Mandarin.

\section{Case 2: Anong, a Tibeto-Burman language of Yunnan}

The Anong people live surrounded by Trung, Rawang, Lisu, Bai, and Chinese speakers. The relevant subgrouping relationships are transparent, with Chinese being the Sinitic side of SinoTibetan and the remaining languages being Tibeto-Burman. Bai, which I personally subgroup as Tibeto-Burman, is so heavily Sinicized that it is frequently classified as Sinitic; in any case, its precise subgrouping is irrelevant since there is no evidence that it has had any effect on Anong. Lisu is, like Anong, a Tibeto-Burman language, but it uncontroversially subgroups in the LoloBurmese branch of Tibeto-Burman, its subgrouping attested to by well worked out sound-meaning correspondences. Lisu is the lingua franca in the Anong speaking area, although Chinese is steadily taking its place. The remaining subgroup relevant to our discussion we can term Anong-TrungRawang; it is a tight-knit subgroup that is uncontroversial. The members are Anong (an autonym), Trung [tə̌rùn] (Chinese exonym: Dulong; population c. 6000 (LaPolla 2000:282-283, 2003)) and Rawang. In all cases, it can be determined whether a lexeme is Chinese, Lisu, or Anong-TrungRawang.

Anong is dying; the majority of the ethnic Anong no longer speak Anong, most having shifted to Lisu, with a small number having shifted to Chinese, and even a few reportedly having shifted to Bai. Ethnic Anong who still speak Anong are now found primarily in the villages, such as Mugujia, Kashi, Muleng, Lagagong, Aniqia, and Lahaigong, which belong to the Mugujia Township of Shangpa Town in Fugong County, but now fluent speakers are only found in Mugujia. 


\subsection{Contact-induced restructuring}

Besides its clarity, what makes this data important is that Sun and Liu (Sun \& Liu 2005, 2009) have documented much of the total restructuring of the language over the half century. They began recording the data in 1960; since then they have returned regularly, recording the changes almost as they occur. Thus, the Anong data has a relatively precise time frame and clear, richly attested diachronic data.

\subsubsection{Phonology}

Since Sun's first recordings in 1960, significant changes have occurred. In 1960, there were initial preglottalized stops; by 1999, except for a few of the oldest speakers, these had disappeared, sometimes being replaced by tense vowels; the lack of initial preglottalized stops and the presence of tense vowels are both features of Lisu. Anong lacked tense vowels in 1960; by 1983 there was tenseness in vowel and nasal codas but tenseness did not seem to have any grammatical functions; but, by 1999 the minimal pairs involving tense versus non-tense vowels had not only fully come into being, but tenseness was present as the contrast in minimal pairs with Sun noting that by 1999 tenseness sometimes marked grammatical meaning. In the 1960s, Anong clusters with retroflex consonants existed; by 1999 they had been simplified; speakers under 50 no longer have them; simple retroflexes are similarly disappearing. In addition, new free variation has been introduced; the alveolar and palatal affricate series, once distinct, now vary freely, as in Lisu. In each case, the change makes Anong more Lisu like. ${ }^{21}$

\subsubsection{Lexicon}

In a paper written in 1999, Sun notes (1999a:354) that Anong now frequently uses Lisu words in place of common Anong words. He further comments that the numeral system has begun to disappear; some fluent speakers could count to a hundred, but the less fluent only used Anong for numbers up to ten, using Lisu otherwise. Sun (1999a:354) reports that of 2,600 words recorded in 1960, some 8\% were from Lisu and another 5\% were from Chinese; in 1999, the Lisu loans constituted around $17 \%$, while the Chinese were around $8 \%$. In Thurgood \& Li (2003b), we compiled our own list of Lisu loans, based on whether the pattern of sound correspondences shows a form to be originally Lolo-Burmese (the subgroup containing Lisu) or Anong-Trung-Nu-Rawang (the subgroup containing Anong). ${ }^{22}$ Our list, restricted of course to forms for which sound correspondences could be established, shows a similarly high percentage of loans.

\subsubsection{Grammar}

Many of the Anong linguistic subsystems have been totally restructured in the last forty years. Sun's earliest recorded Anong displayed a rich system of affixes. However, since that time, some of the categories have come to be restricted to elderly speakers, having largely disappeared in the speech of the only slightly younger.

Other systems have restructured just as dramatically over the last forty years. Both the fluent speakers (all over 60 years old) and the semi-fluent speakers (of various ages) speakers still retain the subject agreement, but for semi-fluent speakers, most of the number marking has also disappeared (for fluency criteria, see page 54). Sun \& Liu (2009:138) note that in the singular first

${ }^{21}$ Not all changes are driven by Lisu. Some are Chinese influenced like the vowel $/ \mathrm{l} /$, which only occurs in Chinese loans. Still others appear not due to limited access to the language resulting in incomplete learning; they occur in the speech of Anong who lack fluency in the language (Sun \& Liu 2009).

${ }^{22}$ In both of these cases, borrowings provide irregular correspondences providing reliable identification of loans. 
person subjects are marked in the fluent and semi-fluent speakers with $-\eta$, but in the semi-fluent speakers the dual $\left(s \varepsilon^{55}\right)$ is lost as is the first person plural $\left(-i^{3 I}\right)$ and second person plural $\left(\eta \mathcal{u}^{3 I}\right)$.

Table 9. Agreement systems (fluent and semi-fluent).

\begin{tabular}{|c|c|c|c|}
\hline number & person & Fluent & Semi-fluent \\
\hline \multirow[t]{3}{*}{ singular } & 1 & $a^{31} n_{\varnothing \varepsilon \eta^{35}}$ & $a^{31} n \varepsilon n^{35}$ \\
\hline & 2 & $\eta a^{31} \eta \varepsilon^{33}$ & $\eta a^{31} n \varepsilon^{33}$ \\
\hline & 3 & $\mathrm{a}^{31} \mathrm{ng}^{\varepsilon^{33}}$ & $a^{31} n \varepsilon^{33}$ \\
\hline \multirow[t]{3}{*}{ dual } & 1 & $a^{31} n \varepsilon^{33} s \varepsilon^{55}$ & $\mathrm{a}^{31} n^{\varepsilon^{33}}$ \\
\hline & 2 & $\eta a^{31} n \varepsilon^{33} s \varepsilon^{55}$ & $\eta a^{31} n \varepsilon^{33}$ \\
\hline & 3 & $a^{31} n \varepsilon^{33}$ & $a^{31} n \varepsilon^{33}$ \\
\hline \multirow[t]{3}{*}{ plural } & 1 & $a^{31} n \varepsilon^{33} i^{31}$ & $a^{31} n \varepsilon^{33}$ \\
\hline & 2 & $\eta a^{a^{31}} \eta \varepsilon^{33} \eta u^{31}$ & $\eta a^{31} n \varepsilon^{33}$ \\
\hline & 3 & $a^{31} n \varepsilon^{33}$ & $a^{31} n \varepsilon^{33}$ \\
\hline
\end{tabular}

Source: Sun \& Liu (2009:138)

As Sun \& Liu (2009:138) write the fluent speakers are all over 60, but for the remaining speakers, the variation does not vary according to age, but mainly varies according to proficiency.

The nominal morphology: The case marking particle system has largely been lost by speakers under 50: the $m i^{{ }_{3}}$ instrumental case marker is still used, but the causative marker $m i^{{ }_{3}}$ is no longer used; the recipient marker $b a^{31}$ is no longer used, the locative marker $t h a \eta^{53}$ is only sometimes used, and the possessive marker $k^{h} a^{31}$ is no longer used.

Much of this change seems to be the attrition that occurs in the late stages of language death, but in some of the changes the influence of Lisu can be seen. One example of borrowing is the Lisu agentive suffix $s u^{55}$, which looks to be at least semi-productive.

Causatives: The older system of forty years ago, which is almost identical to the modern system of closely-related Trung, would be quite familiar to students of Tibeto-Burman languages: it marked most causative forms by prefixing $s u^{55}$ - (or $6 i^{31}$ - before palatals) to the basic root. The system is morphologically simple, largely productive, and readily transparent.

The new Anong causative system is no longer morphological, no longer productive, and anything but transparent: instead, it is lexical-causatives are learned word-by-word. The newer contemporary system, recorded in 1999, is much messier: the older, easily-segmentable prefix + root combinations have undergone considerable assimilation, with the former prefixes fusing with the initial of the root; this has resulted in a system in which the simplex forms (i.e., non-causative forms) are distinguished from the causative forms by differences in the root-initial consonants. For a learner, the causatives have to be learned one-by-one; for the learner, the causatives are now suppletive.

While similar breakdowns in the old Tibeto-Burman causative system have occurred elsewhere (e.g., Matisoff 1972; Thurgood 1977, 1981), nowhere else do we have documented evidence of so extensive restructuring in such a short time frame. In a recent paper, Sun (1999a:355-356) notes that in 1983, the Anong used by an older speaker (a 70 year old) double marked causatives, using both the inherited Proto-Tibeto-Burman (PTB) prefix and transparently-related changes in the verb roots; thus, the older system morphological system had been augmented by subsequent phonological assimilation. However, doing additional fieldwork in 1999, just sixteen years later, Sun's reports (1999a:355-356, 1999b) that the causative system used by his new language assistant 
did not include many of the forms used by the 1983 language assistant. Sun states that, while some speakers claimed to recognize the older forms, others did not; some suggested that the system had undergone simplification.

Table 10 exemplifies one of the differences between the oldest, most conservative speakers and others.

Table 10. Anong causatives (older vs. middle-aged speakers).

\begin{tabular}{|c|c|c|c|}
\hline verb & $\begin{array}{l}\text { causatives } \\
\text { (older speakers) }\end{array}$ & $\begin{array}{l}\text { causatives } \\
\text { (middle-aged } \\
\text { speakers) }\end{array}$ & gloss \\
\hline $\begin{array}{l}\mathrm{y}^{55} \\
\mathrm{ni}^{55} \\
\mathrm{ga}^{55} \\
\mathrm{ba}^{55} \mathrm{a}^{31}\end{array}$ & $\begin{array}{l}6^{31} \mathrm{dzuwn}^{55} \\
\mathrm{ci}^{31} \mathrm{ni}^{55} \\
\mathrm{su}^{55} \mathrm{ga}^{55} \\
\operatorname{su}^{31} \mathrm{ba}^{55} \mathrm{a}^{31}\end{array}$ & $\begin{array}{l}\operatorname{ctcumy}^{55}>\mathrm{t}^{\mathrm{h}} \mathrm{urn}^{55} \\
\mathrm{ni}^{55} \\
\mathrm{k}^{\mathrm{h}} \mathrm{a}^{55} \\
\mathrm{p}^{\mathrm{h}} \mathrm{a}^{55} \mathrm{a}^{31}\end{array}$ & $\begin{array}{l}\text { cause to be broken } \\
\text { cause to know } \\
\text { cause to be broken }\end{array}$ \\
\hline
\end{tabular}

Source: Sun (1999b:195); transcription slightly modified.

The forms correlate with recent changes in the patterns of language use. The older layer of Anong causatives are still seen in the causatives of closely related Trung: Table 11 shows the older causatives attested in older Anong speakers resemble the causatives of Trung, while the newer causatives used by middle-aged (and younger) speakers are now quite distinct. Note that for many forms multiple variants exist, primarily depending on age of the speaker and fluency; for example, for 'be broken' there are $6 i^{31} d z m \eta^{55}, 6 t 6 m \eta^{55}$ and $t 6^{h} u \eta^{55}$, all counterparts of the simplex $d z m \eta^{55}$.

Table 11. Modern Trung (Dulong) causatives vs. older Anong causatives.

\begin{tabular}{|c|c|c|c|c|c|}
\hline \multicolumn{2}{|c|}{ Trung (Dulong) } & \multicolumn{2}{|l|}{ Anong } & \multirow[b]{2}{*}{ newer causative } & \\
\hline verb & causative & verb & older causative & & \\
\hline $\begin{array}{l}\operatorname{lump}^{55} \\
\text { dumm }^{55}\end{array}$ & $\operatorname{su}^{55} \mathrm{dum}^{55}$ & $\operatorname{dim}^{55}$ & $\begin{array}{l}61^{11} 11 m^{5} \\
63^{31} \operatorname{dim}^{55}\end{array}$ & $\operatorname{ctim}^{55}>\mathrm{thim}^{55}$ & $\begin{array}{l}\text { bury } \\
\text { collap }\end{array}$ \\
\hline$\eta w^{5_{3}}$ & $\mathrm{sum}^{31} \mathrm{yu}^{5_{3}}$ & yum $^{55}$ & $\mathrm{su}^{31} \mathrm{yu}^{55}$ & now $^{55}$ & \\
\hline
\end{tabular}

Source: Sun (1999b:194-195)

\subsection{Language contact patterns: the Anong contrast with Trung}

Forty years ago, the Anong and Trung might have been considered dialects. Since then, Trung has undergone only moderate change, while Anong has completely restructured. Why did Anong change so radically? Certainly the answer is not structural; if it were, both should have undergone roughly equivalent changes, but they have not. The answers are found in the social settings.

Speakers, numbers, and fluency. The apparent similarity between the population figures for Anong (c. 6500) and those for Trung (c. 6000) is misleading: the government population numbers reflect ethnic affiliation, not the number of speakers. It is in the number and age of the speakers that striking differences between the Anong and Trung can be seen. Trung is still a viable language: it has younger speakers, and is used for a wide range of purposes. And, quite significantly, for the Trung it is the Trung language that is pervasive, not Lisu. In contrast, Anong is a language on the edge of extinction, under intense pressure from Lisu as a local language and from Chinese as a 
language of wider communication, with only 400 or so remaining Anong speakers, and of these, only roughly $12 \%$ are fluent.

In a 1999 paper, Sun (1999a:353-355) reports his survey of some 104 people from 25 households-roughly a quarter of all the Anong speakers, located in Mugujia village, the area where Anong is the most concentrated. The survey checked their fluency in Anong, in Lisu, and in Chinese, in terms of four levels of linguistic competence, here called Levels A, B, C, and D. These levels are described below, as they apply to Anong.

- Level A-Fluent: Level A speakers are able to engage in everyday conversation as well as describe food production and daily living and are able to use over 3,000 basic items of vocabulary. All over 60 years old.

- Level B-Semi-fluent: Level B speakers can engage in everyday conversation, but not very fluently and able to use around 1,000 basic words. Level B speakers are better in their second language than in Anong.

- Level C-Limited: Level C speakers are only able to use daily greetings or a few everyday phrases and, thus, are unable to use Anong to express themselves adequately and completely. Their Anong frequently includes words from their second language. They only use a limited number of Anong vocabulary items, with much of the basic vocabulary missing. Their pronunciation of Anong is inaccurate. In contrast, they are very fluent in their second language.

- Level D-Non-speakers: Level D respondents have essentially lost their mother tongue, although some can still understand a little, but they can no longer speak their mother tongue. In fact, some have completely lost their Anong.

Table 12 puts Sun's (1999a:353-355) numbers together in table form. Examination of the Anong column shows some 62 individuals in Mugujia village are still fluent in Anong (using the criteria above). However, as Sun (1999a:354) writes, outside of Mugujia village, there are virtually no fluent Anong speakers left. As of 2009, these 62 are the last fluent speakers - all of them now over 70. Sun also found some 19 semi-fluent speakers in the Mugujia sample and outside of the Mugujia area there are semi-fluent speakers left, in his estimation roughly 280 (1999a:254). In sum, as of 1999 there were roughly 62 fluent Anong speakers and perhaps a little over three hundred semi-fluent speakers remaining. ${ }^{23}$

Table 12. Fluency rates in Anong, Lisu, and Chinese.

\begin{tabular}{lllllll} 
& Anong & \multicolumn{3}{c}{ Lisu } & \multicolumn{3}{c}{ Chinese } \\
Proficiency & $\#$ & $\%$ & $\#$ & $\%$ & $\#$ & $\%$ \\
& & & & & & \\
A. Fluent & 62 & $59.6 \%$ & 96 & $93 \%$ & 13 & $12.5 \%$ \\
B. Semi-fluent & 19 & $18.2 \%$ & 8 & $7.7 \%$ & 17 & $16.3 \%$ \\
C. Limited & 14 & $13.4 \%$ & 0 & $0.0 \%$ & 19 & $18.3 \%$ \\
D. Non-speakers & 7 & $8.8 \%$ & 0 & $0.0 \%$ & 55 & $52.6 \%$
\end{tabular}

\footnotetext{
${ }^{23}$ There are now fewer than 62 speakers, but precisely how many fewer is unknown.
} 
There are unanswered questions with Sun's survey. For instance, for Level C, Sun says that they are very fluent in their second language; for these speakers, perhaps Lisu was their first language. For Level D, Suns talks about speakers losing their first language; it is likely that they never spoke Anong fluently. However there is no reason to question Sun as he observes (1999a:353-355) that a closer look at the 62 fluent speakers of the 104 Anong speakers in Mugujia village shows how close the language is to being lost. As the next column indicates, of the 104 Anong surveyed (including the 62 fluent speakers), 96 of them-all but 8-are fluent in Lisu. All 8 of those not fluent in Lisu were elderly people who rarely went out. Thus, as Sun notes, that even in the village where the highest concentration of Anong speakers was found, the proficiency and level in Lisu has already surpassed that of Anong. Further, as he notes, almost all the Anong, including most of the fluent speakers, can speak Lisu and most can speak it better than Anong.

The situation with Chinese, the final pair of columns, seems quite different. While Sun's numbers show some $30 \%$ of the Anong as fluent or semi-fluent in Chinese, ${ }^{24}$ those who were fluent in Chinese were almost all middle-aged or younger and had secondary school level educations or higher and for the most part those who were semi-fluent in Chinese frequently had either a primary school education or had at least attended school. As a consequence of this schooling, fluent and semi-fluent speakers of Chinese had more opportunities for interaction outside the village.

Usage patterns. Although clearly not the same thing, usage patterns do correlate with the loss of fluency as the loss of domains of use restricts opportunities for contact with the language. Sun (1999a:354) writes that Mugujia village has both the highest concentration of Anong speakers and, not surprisingly, the highest usage of Anong. As Sun observed, in Mugujia village it was possible to hear conversations in Anong, although even here most people spoke in Lisu.

Outside of Mugujia village Anong usage falls off sharply. Although Anong speakers also live in other villages around Mugujia-Kashi, Muleng, Lagagong, Aniqia, and Lahaigon, in these areas the Anong often are less concentrated, living interspersed with concentrations of Lisu or with people of other nationalities. In these areas, Sun (1999a:354) notes, there are essentially no remaining Anong speakers who are fully fluent. In these areas, Sun (1999a:354) counted some 280 semi-fluent speakers, with most being elderly people in their 60 s or $70 \mathrm{~s}$. Among the slightly younger speakers, the Anong in their 50s or $60 \mathrm{~s}$, only a handful could still speak their mother tongue even at the semifluent level. Sun (1999a:354) attributes this to the lack of opportunity to use Anong in their daily lives; most, he notes, only used a few sentences and then only use these when speaking to the elderly. In these areas, Lisu was the language used for daily communication.

Demographics, usage, and restricted access. As Sun suggests (1999a:354), the patterns of multilingualism severely restrict access to the language. The Anong have interacted with various ethnic groups in the Nujiang River area, but especially with the Lisu. In conversations, unless all individuals spoke Anong fluently, the common language would, of course, have been Lisu. In the case of intermarriage where an Anong had married someone from another group, the same pattern held: even though only one member of the family did not speak Anong, the common language was Lisu, with the non-Anong only very rarely learning some Anong. Sun (1999a:354) observed that even in the rare villages where the Anong were the majority, few non-Anong learned Anong.

Sun (1999a:354) illustrates the typical language in the case of intermarriage by describing the patterns of his Anong language assistant. His assistant was fluent in Anong, but his wife was Lisu. They had been married 30 years, but even after 30 years, she spoke only a little Anong and even that rarely. Lisu was the common language in the family: the three daughters and the son, like the

24 Typically the Chinese spoken is a local Chinese dialect different both from the Kunming dialect spoken in the region and from the national language Putonghua. 
mother, only understood a little Anong, and none could speak it. Occasionally, the father would use a little Anong at home, but they would still answer in Lisu.

In sum, Anong tends to be restricted to situations where all participants speak it fluently: the default language is virtually always going to be Lisu. Thus, only fluent Anong speakers tend to have access to Anong; those less fluent in Anong only have very restricted access to the language.

\section{Conclusions and speculation.}

One mechanism involved in the loss of Anong is simple replacement, generally by Lisu, a development undoubtedly exasperbated by limited usage and limited access to Anong, facilitated by restricting the domains in which Anong is used. Anong forms that are used infrequently are more easily forgotten; Lisu forms that are used frequently are more readily retrieved. All Anong speakers, even the most fluent, probably show some evidence of simple replacement; Sun cites the example of one of his best language assistants substituting the Anong form for 'very' with its Lisu equivalent. With less frequent usage, replacement should go up; with less proficiency, replacement should go up.

Other factors also come into play; one is attitudinal. Sun (1999a) notes that many of the best educated Anong are relatively indifferent to the impending loss of Anong, expressing the view that not only is this the general trend but also noting that they realize that there is little they could do about it in any case. It is worth noting that, while Anong is their first language, the language they are losing is neither their only language, nor their most useful language, nor even the language that they are most fluent in; almost all Anong speak Lisu better than Anong and use it for more purposes.

The shift to Lisu was well underway before the founding of the People's Republic of China in 1949; in fact, it must have been well underway at the time of Barnard's 1934 (1934:89) grammatical sketch and glossary of closely related Rawang which lists as the Rawang term for Lisu the word Anung, indicating that for the Anong Lisu was already so dominant that Barnard treated them as a group of Lisu. However, it is only in the last 30 years or so that the decline in the numbers of speakers and the increasingly restrictive usage patterns have produced the massive restructuring of Anong, not just in its causatives, but in all its systems.

Thus, it is obvious that the changes are a response to language contact and subsequent changes in usage patterns. Sun's description makes it clear that, even for those who knew some Anong, Lisu was the language of choice, not just outside the household, but also in many cases within the household. It is clear that the older generation of Anong speakers is the last generation to successfully learn Anong. The middle-aged and younger speakers have not done so. And, as already observed, this failure to learn Anong correlates with the rapid restructuring and with the increasingly restricted usage and access. In this sense, access to Anong has become too restricted to be successfully passed on; the middle-aged and the younger Anong do not seem to be learning it.

The severely limited access might provide a key to understanding the nature and direction of the restructuring. An examination of the restructuring Anong causatives reveals a series of changes that, although they occurred unusually rapidly, are widely attested throughout other Tibeto-Burman languages. For instance, all of the following developments are found in other Tibeto-Burman languages: a prefixal $s \mathrm{u}^{31}$ - losing its unstressed vowel, fusing with the following root, devoicing a root initial stop or nasal, and then dropping. Complicating the picture, however, is the side-by-side existence of an older pattern often accompanied by more than one newer form.

The path of change may reflect a path found in first language acquisition: normal transmission undoes both phonetic and morphological changes; that is, children learners regularly 'repair' their own phonetically motivated changes to make them conform to what they perceive as more accurate pronunciations. The repairs in morphology are a little more sophisticated but produce a similar 
result. Initially, the learner seems to simply acquire morphology as a series of individual tokens. At a later stage, learners often recognize a morphological pattern, and, in part, restructure earlier forms on the basis of their generalizations - in the case of causatives by putting the prefix before the basic root. Later, some phonetically motivated changes that occurred in the token stage of acquisition are at least partially undone when the learner recognizes the morphological pattern, in the case of causatives putting the prefix before the basic root-thus, connecting in some sense the unprefixed root with the prefixed root. This second stage, generalizing the pattern, has a tendency to undo the phonetic effect of the prefix on the root initial: the causative is reanalyzed each generation as a prefix plus the root. In Anong, however, the younger learners of Anong seem to have never gotten beyond the stage of learning individual tokens - essentially because they lacked sufficient access to language. The result was the connection between the basic root and the causative root was lost. The fact that Lisu uses a lexical approach too probably played a minor role, but the major impetus to restructuring came from increasingly restricted access to the language, a restriction that made the morphological patterns too rare and thus too obscure to learn. The phonetic tendencies explain how the changes took place; the loss of sufficient access to the language explains why it was in the last forty years that they occurred.

\subsection{Summary}

The overwhelmingly majority of the Anong have switched to Lisu, leaving only a handful of individuals still speaking Anong. Even among those fluent in Anong, their Lisu is more fluent than their Anong (with the exception of several elderly, essentially house-bound Anong). Thus, Anong is no longer a language with a well-defined function, and it is certainly not a language used with outsiders.

\section{Case 3: Eastern Cham, a Chamic language of Vietnam}

Cham has been spoken on the coast of Vietnam for over two thousand years; nonetheless, Cham is still linguistically transparent. For instance, overt marking of morphology and syntax, and in cases where grammaticalization of a morpheme has occurred the source morpheme is almost always still present. Some of this transparency, however, seems to reflect earlier language contact. It is clear that the language was under intense contact with Mon-Khmer languages of Vietnam (overwhelmingly Bahnaric; Sidwell, p.c., 2007, 2008).

Eastern Cham ${ }^{25}$ (Phan Rang Cham), a direct descendant of Proto-Chamic, most likely began to split off from Western Cham sometime after the fall of Vijaya in $1471 .{ }^{26}$ In the last 50 years or so, it has come under increasing influence from Vietnamese, however, focuses on the sources of changes before this time.

The linguistic evidence makes it clear (Thurgood 1999) that there was widespread bilingualism between the first Chamic speakers and Mon-Khmer (MK) speaking peoples. Certainly the

\footnotetext{
${ }^{25}$ As Brunelle suggested (p.c.), it is useful to note that the data is from the works of the Bloods. Doris Walker Blood (1978:131) write that the texts used were from a specific informant, Thiên Sanh Canh, who was one of the last of the traditional Cham scholars. Thiên Sanh Canh knew the language of the manuscripts, a formal variety (what Brunelle (2008a, 2009) calls the $\mathrm{H}$ variety). The significance of this, as Brunelle points out and the Bloods were aware (Blood 1961, 1977, 2008), is that this particular variety probably reflects a variety of the language that was already falling out of use in the 1960s.

${ }^{26}$ There is certainly no hard evidence. It would be after 1471 that the dominance of Chamic would have begun to wane, but it is likely that various groups fled to Cambodia at different times. Brunelle (p.c.) points out that Po $(1987,1991)$ refers to manuscripts mentioning Chams fleeing to Cambodia as late as the early $19^{\text {th }}$ century. Brunelle also suggests, quite plausibly, that such a scenario could explain the surprising dialectal diversity in Cambodian Cham.
} 
reconstructions of Proto-Chamic show this contact: there are roughly under $300 \mathrm{MK}$ borrowings including body part terms and other basic vocabulary.

In addition, examination of the phonology of Proto-Chamic suggests something about the language use patterns at the time of the formation of PC. Table 13 shows the Proto-Austronesian (PAn) main vowel system and its reflexes in PC; Table 14 shows the PC system with the vowels borrowed from a MK source (Thurgood 1998, 1999:126).

Table 13. The inherited PC main syllable vowels?

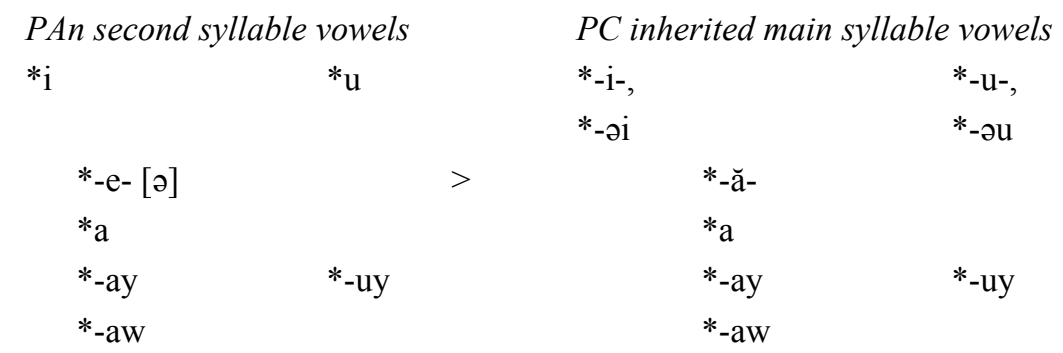

Table 14. PC main syllable vowels, inherited and borrowed.

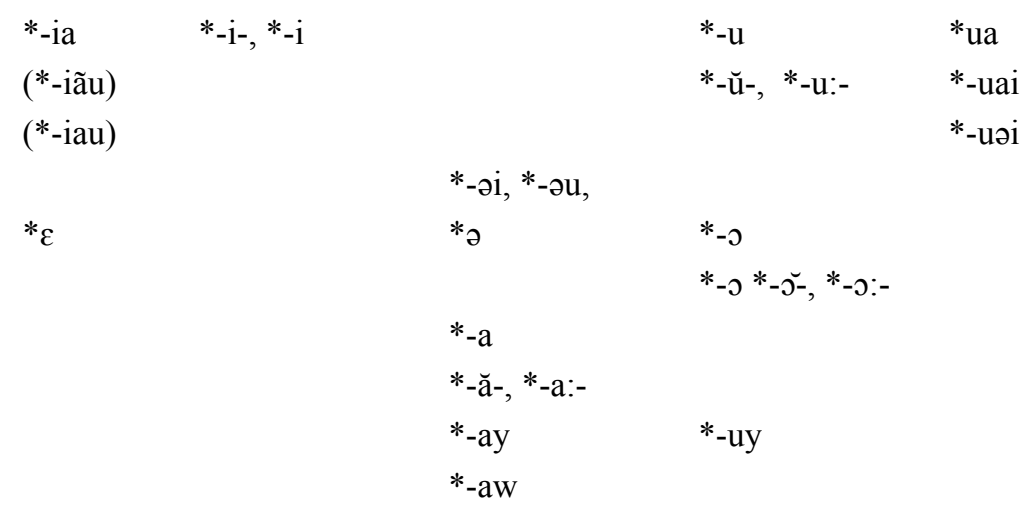

One of the reviewers suggested the explanation: shifting speakers often carry over features from their L1 leading to more complex features in the target language. In this case enough non-tutored adult learners, Mon-Khmer speakers, began to use Chamic to provide not only some of the impetus for the restructuring of the vowel system, but also to help simply the grammatical system. Whether these Mon-Khmer speakers shifted to Chamic or simply became bilingual is probably not of major importance; both conditions would most likely have produced similar outcomes.

Other factors undoubtedly played a role. Until quite recently when the Eastern Cham increasingly began to learn Vietnamese, Eastern Cham was the dominant language for most of the Eastern Cham speakers, serving both as a language of the home and the village. Brunelle (p.c.) suspects that Cham was a regional lingua franca before the fall of Panduranga in 1832, and was more widespread before that data. However, as Brunelle argues (p.c., citing Po Dharma's work), it could not remain a lingua after then because contacts with other minority groups were mostly lost then. Sidwell $(2007,2008)$ argues that it was likely that Cham was a lingua franca in the Central Highlands during some periods, but there is no clear evidence of shift to Cham after the ProtoChamic stage. In any case, it would be difficult to argue on the basis of this to argue for shift in numbers significant enough to bring about structural change. 
In addition to contact produced restructuring, it is also necessary to consider the possibility that the Malayic language that came into contact into Proto-Chamic was already learnable ${ }^{27}$ when the original speakers first arrived - there is a long history of shift into Malay(ic) throughout the region.

In any case, it is clear from the linguistic record that contact restructured PC; it is not as clear what effect the two thousand years of language shift and bilingualism that occurred after PC had, contra my earlier writings, because we know too little about the patterns and amount of shift and too little about the functioning of Cham as a lingua franca. However, what still remains to be explained is the continued transparency of the language structures.

\subsection{Contact-induced restructuring}

\subsubsection{Phonology and the lexicon.}

The morphemes of Eastern Cham are never less than a syllable and, aside from the possibility that the causative marking $p a$ - is still marginally productive, the morphemes are overwhelmingly separate words (Thurgood 2005).

\subsubsection{The lexicon}

The lexicon shows the ancient influence of contact with Mon-Khmer languages (Thurgood, 1999; Sidwell, p.c., 2007, 2008) and much more recent contact with Vietnamese (Thurgood 1999). ${ }^{28}$ Of particular interest is the trend toward monosyllabification-some of which predates heavy Vietnamese influence. This paper focuses on much older developments.

\subsubsection{Grammar}

The grammar is typical of the what is common to three quite distinct areas of study: the early stages of first language acquisition, the earliest stages of grammaticalization, and universal patterns (Thurgood 2005).

\subsubsection{The patterns}

Aspectual marking, no tense. Eastern Cham lacks tense, but optionally indicates the basic aspectual distinctions, using the forms too? 'live; stay' > 'still' > 'PROGRESSIVE' and $p l i h$ 'finish' > 'PERFECTIVE' to distinguish ongoing states and activities from completed ones, not just on the verbal level (in the verb morphology) but also on the clausal level (at the onset of a clause).

Other periphrastic patterns. Other Eastern Cham periphrastic patterns include a causative from 'make', a permissive from 'give', a quotative from 'say', a reflexive from 'body', recipient, experiencer, and change-of-state marking from 'get; receive', locative nouns from nouns meaning 'top', 'bottom', and 'back', and prepositions that mark basic relationships, e.g., 'INSTRUMENTAL' and 'BENEFACTIVE'.

\subsubsection{Word order}

Eastern Cham has a rigid SVO word order (WO). There is little morphology: the subject and the object are marked primarily by word order, while indirect objects are marked with a preposition. Except where subject deletion serves to mark cohesion between clauses, subjects are retained. The genitives are marked by simple juxtaposition, with the head noun first and the genitive following. Most other sentence types are minimally altered variants of the declarative clause, generally

\footnotetext{
${ }^{27}$ Many of the structures of Eastern Cham are semantically compositional, that is, the meaning of the whole is predictable from the sum of the parts. The assumption being made is that semantically compositional parts of the grammar are easier to learn and are, all things being equal, learned early by those acquiring a second language.

${ }^{28}$ See, Aymonier (1889); Blood (1961); Alieva (1991, 1994); Brunelle (2008b, 2009).
} 
modified by sentential particles at the periphery of the clause, thus keeping the basic clause configuration unaltered. As might be expected, questions follow the same word order as the corresponding declarative sentences. Questions answerable with a yes or no typically are signalled with nothing more than a rise in intonation on the last element in the sentence (Doris Blood 1977:42). Occasionally a yes/no question is signalled by the sentence-final particle laay 'Q'. Content questions, like yes/no questions, use the same word order as the corresponding declarative sentences, but with the question word inserted in place of the questioned item. Where explicitly marked, modality is indicated by an abundance of sentence final particles. In colloquial speech, negation is simply shown by the sentence-final $o$ 'NEG'.

Interclausal cohesion is accomplished by heavy reliance on juxtaposition augmented at times by the deletion of the coreferential subject to show cohesion between two clauses. Clause-final particles may also be used to mark interclausal cohesion. Transparency is further attained by a strong preference for chronological sequencing.

Only subject relative clauses occur, and even these are restricted in the materials examined to designation of locations, times, and the like. As with clausal cohesion subject relative clauses delete the coreferential subject.

An explicit purpose clause exists which is marked with the grammaticalized pyzh 'in order to', where the purpose clause might not be readily inferable from context. In either case, if the purpose clause has an explicit subject, as with wish-clauses, the subject is marked with the preposition $k a$ 'for; BENEFACTIVE'.

Serial verb patterns exist, involving the deletion of co-referential subjects and the juxtapositions overwhelmingly but not exclusively match the chronology of the events.

Eastern Cham with its rigid SVO order and its preference for semantically compositional structures devotes a minimum of special syntactic machinery to discourse concerns: in fact, Eastern Cham seems to have only those discourse pragmatic markers common to almost all languages: topicalization, left dislocation, and a presentative. The presentative clauses (or, existential clauses) introduce new entities onto the main stage. In the main verb uses, the subject appears in normal position before the verb $h u$ 'have; get' (Thurgood \& Li 2007). Left-dislocation, as the term indicates, involves movement of an object to the beginning of the clause.

Most of the participant tracking in the text is done by indexicals - kinship terms which are used pronominally with humans to index personal and social identity, and by classifiers occurring neither with numbers or other modification, which are used with other animates and objects to designate things already established in the discourse. Much more rarely pronouns are used but in the texts typically only when no possibility of ambiguity exists, usually because just a single major participant is being tracked.

In short, what marks Eastern Cham is its semantic compositionality, its relative lack of morphological marking, and its high dependence on chronological sequencing. The source morphemes still exist as such and the path of development is transparent, and, thus, easily learnable.

\section{Conclusions}

The data in this paper is presented, not for the answers the data provides, but for the questions it asks. Nonetheless, for these languages, it is at least clear that the primary determinants of the paths of change are social factors - the patterns of language use, the stability of bilingualism in various social settings, and, probably, population size, to name only a few. For Hainan Cham, although the emergence of Chinese as the dominant language seems to have set the changes in motion, its stability lies in its function as the language of the home and the village. The restructuring has been 
further promoted by the fact that Hainan Cham is never used for wider communication, but instead other languages are used to speak to outsiders.

For Anong, the switch to Lisu in virtually every domain has led to the total restructuring of Anong - only a handful of the oldest speakers, those with less access to Lisu and less proficiency in it, have managed to avoid major restructuring. Here, the restructuring of Anong has been promoted by the prominence of Lisu and by the fact that Anong is generally only used to talk to other Anong speakers, and, then, usually only to one of the other 60 or so fluent Anong speakers. All the functions once performed in Anong are now done in Lisu.

For Eastern Cham the story is different. Until the emergence of Vietnamese it was an important language in the region, but it no longer is. However, as Brunelle writes (2005, 2008a, 2009), the language is still very strong in most villages of Ninh Thuan and in the north of Binh Thuan. Brunelle notes that the only area where the language seems to be losing ground is in the village is Southern Binh Thuan (close to Phan Thiet), where villages are mixed. ${ }^{29}$ Nonetheless, although the number of speakers is still robust (c. 100,000), its future is not promising.

In general terms, the lack of a function is the greatest threat to these languages. Sun's Anong now lacks a function and will disappear with this generation. Hainan Cham will survive only until the advantages of living in the village disappear; then the village along with Hainan Cham will disappear. Eastern Cham will face similar problems; it will take a little longer, but it will also disappear. Before this happens, it is crucial to recognize that each well documented case of language contact provides significant input into our understanding of languages in contact, and thus, in essence, to our understanding of the structural influences of multilingualism.

\section{References}

Alieva, Natalia F. 1991. Morphemes in Contemporary Spoken Cham: Qualitative and Quantitative Alternations. Cahiers de Linguistique Asie Orientale 20-2:219-229.

Alieva, Natalia F. 1994. The progress of monosyllabicization in Cham as testified by field materials. In: Cecilia Ode \& Wim Stokhof (eds.), 541-549. Proceedings of the Seventh International Conference on Austronesian Linguistics (ICAL). Amsterdam: Rodopi.

Andersen, Henning. 1988. Centre and periphery: adoption, diffusion, and spread. In: Jacek Fisiak (ed.), 39-85. Historical dialectology. Berlin: Mouton de Gruyter.

Aymonier, Étienne François. 1889. Grammaire de la langue chame. Saigon : Imprimerie coloniale.

Barnard, Joseph Terence Owen. 1934. A handbook of the Rawang dialect of the Nung language, containing a grammar of the language, colloquial exercises and a vocabulary with an appendix of Nung manners and customs. Rangoon: Superintendent, Government Printing and Stationery, Burma.

Benedict, Paul K. 1941. A Cham colony on the island of Hainan. Harvard Journal of Asiatic Studies 4:129-34.

Benedict, Paul K. 1984. Austro-Tai parallel: A tonal Cham colony on Hainan. Computational Analyses of Asian \& African Languages 22:83-86.

Blood, Doris Walker. 1977. Clause and sentence final particles in Cham. In: David Thomas, E. W. Lee, \& N. D. Liem (eds.), 39-51. Papers in South East Asian Linguistics $N^{\circ}$ 4: Chamic Studies. Pacific Linguistics Series A.

\footnotetext{
${ }^{29}$ Brunelle (2005:25) has a list of social situations and their associated languages in his dissertation.
} 
Blood, Doris Walker. 1961. Women's Speech Characteristics in Cham. Asian Culture 3(3-4):139143.

Blood, Doris Walker. 1978. Some aspects of Cham discourse structure. Anthropological Linguistics 20-3:110-132.

Blood, Doris Walker. 2008. The ascendancy of the Cham script: how a literacy workshop became the catalyst. International Journal of the Sociology of Language 192:45-55.

Brunelle, Marc. 2005. Register in Eastern Cham: Phonological, Phonetic and Sociolinguistic approaches. Ph.D., Linguistics, Cornell.

Brunelle, Marc. 2008a. Diglossia, Bilingualism, and the Revitalization of Written Eastern Cham. Language Documentation and Conservation 2-1:28-46.

Brunelle, Marc. 2008b. Monosyllabicization in Eastern Cham. SEALS XIV: Papers of the $14^{\text {th }}$ annual meeting of the Southeast Asian Linguistics Society 2004, Bangkok: Pacific Linguistics, 43-58.

Brunelle, Marc. 2009. Diglossia and Monosyllabization in Eastern Cham: a Sociolinguistic Study. In: James N. Stanford \& Dennis R. Preston (eds.), 47-75. Variation in Indigenous Minority Languages. Amsterdam: John Benjamins.

Durie, Mark. 1990. Proto-Chamic and Acehnese mid vowels: towards proto-Aceh-Chamic. Bulletin of the School of Oriental and African Studies 53-1:100-114.

Franke, Wolfgang. 1988. Chinese Epigraphic Materials in Indonesia, Vol. I. Singapore: South Seas Society.

Gumperz, John J. \& Robert Wilson. 1971. Convergence and creolization: a case from the IndoAryan/Dravidian border. In: Dell Hymes (ed.), 151-168. Pidginization and creolization of language. Cambridge University Press.

Haudricourt, André-George. 1984. Tones of some languages in Hainan. Minzu Yuwen 4:17-25. Also published as: La tonologie des langues de Hai-nan. Bulletin de la Société de Linguistique de Paris 79-1:385-394.

LaPolla, Randy J. 2000. Valency-changing derivations in Dulong/Rawang. In: Robert M. W. Dixon \& Alexandra Y. Aikhenvald (eds.), 282-311. Changing Valency: Case Studies in Transitivity. Cambridge: Cambridge University Press.

LaPolla, Randy J. 2003. Dulong, in: Graham Thurgood \& Randy LaPolla 2003, 674-682.

Lee, Ernest W. 1966. Proto-Chamic phonologic word and vocabulary. Ph.D. dissertation. Indiana University. 67-3690.

Maddieson, Ian \& Keng-Fong Pang. 1993. Tone in Utsat. In: Jerold A. Edmondson \& Kenneth Gregerson (eds.), 75-89. Tonality in Austronesian Languages. Oceanic Linguistics Special Publication $\mathrm{N}^{\circ} 24$. Honolulu, Hawaii: University of Hawaii Press.

Matisoff, James A. 1972. The Loloish Tonal Split Revisited. Research Monograph № 7, Center for South and Southeast Asia Studies, University of California: Berkeley.

Ni, Dabai. 1988a. The genealogical affiliation of the language of the Hui people in Sanya Hainan. Minzu Yuwen 2:18-25.

Ni, Dabai. 1988b. The Kam-Tai of China and the Hui of Hainan. Bulletin of the Central Institute of Minorities 3:54-65. 
Ni, Dabai. 1990a. The origins of the tones of the Kam-Tai languages. ms.

Ni, Dabai. 1990b. The Sanya (= Utsat) language of Hainan island: a living specimen of a linguistic typological shift. ms.

Ouyang Jueya \& Zheng Yiqing. 1983. The Huihui language of the Hui nationality of Yaxian, Hainan. Minzu Yuwen 1:30-40.

Po, Darma. 1987. Le Panduranga (Campa) 1802-1835. Paris : Ecole française d'Extrême-Orient.

Po, Darma. 1991. Le déclin du Campa entre le XVI et le XIX siècle. Le Campa et le Monde Malais. Paris: Publications du Centre d'histoire et Civilisations de la Péninsule Indochinoise: 47-64.

Reid, Anthony. 2006. Introduction. In; Anthony Reid (ed.), 1-37. Verandeh of Violence: The Background to the Aceh Problem. Singapore University Press in association with University of Washington Press, 2006.

Shellabear, William Girdlestone. [1961] 1909. Sejarah Melayu (The Malay Annals). Singapore: Malay Publishing House.

Sidwell, Paul. 2007. The Mon-Khmer substrate in Chamic: Chamic, Bahnaric and Katuic contact. SEALS XII: Papers from the $12^{\text {th }}$ annual meeting of the Southeast Asian Linguistics Society 2002, De Kalb: Pacific Linguistics.

Sidwell, Paul. 2008. The origins of the Chamic lexicon: lexification and back-borrowing into MonKhmer languages. SEALS XIII: Papers from the 14th annual meeting of the Southeast Asian Linguistics Society 2004, Bangkok: Pacific Linguistics.

Sun Hongkai. 1999a. Notes on Anong: Observations of its path of gradual decline and loss. Zhongguo Yuwen 272-5:352-357.

Sun Hongkai. 1999b. The category of causative verbs in Tibeto-Burman languages. Linguistics of the Tibeto-Burman Area 22-1:183-199.

Sun Hongkai \& Guangkun Liu. 2005. A description of Anong. New Found Minority Languages of China Series. Beijing: Institute of Minority Studies.

Sun Hongkai \& Guangkun Liu. 2009. A grammar of Anong: Language death under intense contact. Translated, annotated, and supplemented by Fengxiang Li, Ela Thurgood, \& Graham Thurgood. Leiden: Brill.

Thurgood, Graham. 1977. Lisu and proto-Lolo-Burmese. Acta Orientalia 38:147-207.

Thurgood, Graham. 1981. Notes on the origins of Burmese creaky tone. Tokyo: Monumenta Serindica Monograph Series $N^{\circ}$ 9. Institute for the Study of Languages and Cultures of Asia and Africa.

Thurgood, Graham. 1992. The aberrancy of the Jiamao dialect of Hlai: speculation on its origins and history. In: Martha Ratliff \& Eric Schiller (eds.), 417-433. Southeast Asian Linguistics Society I, Tempe: Arizona State University Southeast Asian Studies Publication Program.

Thurgood, Graham. 1994. Radical typological restructuring in Utsat: From disyllabic and atonal to monosyllabic and tonal. Proceedings of Towarzystwo Naukowe w Toruniu [The Academy of Science, Toruñ] 47:1-1.1993-31-12.1993, pp. 48-52.

Thurgood, Graham. 1996. Language contact and the directionality of internal 'drift': the development of tones and registers in Chamic. Language 71-1:1-31. 
Thurgood, Graham. 1998. The development of the Chamic vowel system: the interaction of inheritance and borrowing. David Thomas (ed.), 61-90. Papers in Southeast Asian Linguistics $N^{\circ}$. 15: Further Chamic Studies, Pacific Linguistics Series A-89. Canberra: Pacific Linguistics.

Thurgood, Graham. 1999. From Ancient Cham to Modern Dialects: Two Thousand Years of Language Contact and Change. Oceanic Linguistics Special Publication $\mathrm{N}^{\circ} 28$. Honolulu: University of Hawai'i Press.

Thurgood, Graham. 2003. The causatives in Sun Hongkai's Anong: language death and rapid restructuring. Berkeley Linguistics Society 29:463-471.

Thurgood, Graham. 2005. Phan Rang Cham. In: Alexander Adelaar \& Nikolaus P. Himmelmann (eds.), 489-512. The Austronesian Languages of Asia and Madagascar. New York: Routledge.

Thurgood, Graham \& Randy J. LaPolla. (eds.). 2003. The Sino-Tibetan languages. London - New York: Routledge Language Family Series, Routledge.

Thurgood, Graham \& Li Fengxiang. 2007. The Grammaticalization paths of Proto-Chamic *hu 'receive'. In: Proceedings of the Chicago Linguistics Society 39-1:205-214.

Thurgood, Graham \& Ela Thurgood. 2005. The Tones from Proto-Chamic to Tsat [Hainan Cham]: Insights from Zheng (1997 and from Summer 2004 fieldwork. In: Anthony Grant \& Paul Sidwell (eds.), 247-271. Chamic and Beyond: Studies in mainland Austronesian languages. Pacific Linguistics: Australian National University.

Thurgood, Graham \& Li Fengxiang. 2003a. Contact induced variation and syntactic change in the Tsat of Hainan. In: David Bradley, Randy J. LaPolla, Boyd Michailovsky, \& Graham Thurgood (eds.), 285-300. Language variation: Papers on variation and change in the Sinophere and the Indosphere in honour of James A. Matisoff, Pacific Linguistics. Research School of Pacific and Asian Studies.

Thurgood, Graham \& Li Fengxiang. 2003b. Contact and attrition in Sun Hongkai's Anong: Complementary sources of change. In: Iwasaki Shoichi et al. (eds.), 279-295. Proceedings of the Southeast Asian Linguistics Society XIII, University of Arizona, Tempe, Arizona. Canberra, Australia.

Weinreich, Uriel. 1953. Languages in contact. The Hague: Mouton.

Zheng, Yiqing. 1986. A further discussion of the position of Huihui speech and its genetic relationship, Minzu Yuwen 6:37-43.

Zheng, Yiqing. 1997. Huihui Yu Yanjiu [A Study of Hainan Cham]. Shanghai Yuandong Chuban She [Shanghai Far East Publishers]. 